\title{
Consumer Attitudes to Organic Foods. A Spanish Case Study ${ }^{*}$
}

\author{
MÓNICA DÍAZ DONATE
}

Departamento de Producción Vegetal y Tecnología Agraria, UNIVERSIDAD DE CASTILLA-LA MANCHA, ESPAÑA. E-mail: Monica.Diaz@uclm.es

RODOLFO BERNABÉU CAÑETE

Departamento de Producción Vegetal y Tecnología Agraria, UNIVERSIDAD DE CASTILLA-LA MANCHA, ESPAÑA. E-mail: Rodolfo.Bernabeu@uclm.es

\begin{abstract}
The purpose of the present study is to determine the various factors that influence attitudes towards the purchase of organic food. The methodology consisted in a survey of 463 consumers in the Castilla-La Mancha Region who purchased food items for their homes. A multivariate data analysis was carried out by means of Structural Equation Models (SEM), computed with the maximum likelihood method. Attitudes toward the purchase of organic foods are directly related to consumer lifestyle and are influenced by consumers' attitude towards the environment as well. In this sense, lifestyle and environmental attitudes have a positive influence on the purchase of organic food.
\end{abstract}

Keywords: Consumption, Structural Equation Models, Consumer Behaviour, Food Marketing.

\section{Actitud del consumidor hacia los alimentos orgánicos. Estudio del caso español}

\section{RESUMEN}

El propósito del presente estudio es determinar los diversos factores que influyen en las actitudes de compra de alimentos orgánicos. Para ello se realizó una encuesta a 463 consumidores que compraron alimentos para sus hogares de Castilla-La Mancha. Seguidamente se realizó un análisis multivariante de datos por medio de modelos de ecuaciones estructurales (SEM), calculadas con el método de máxima verosimilitud. Las actitudes hacia la compra de alimentos orgánicos están directamente relacionadas con el estilo de vida de los consumidores y se ven influidos por la actitud de los consumidores hacia el medio ambiente. En este sentido, los estilos de vida y la actitud hacia el medio ambiente tienen una influencia positiva en la compra de alimentos orgánicos.

Palabras clave: Consumo, modelos de ecuaciones estructurales, comportamiento del consumidor, marketing alimentario.

JEL Classification: M31

\footnotetext{
* This paper was conducted within the framework of the "Commercialisation and Marketing of Organic Products in Castilla-La Mancha" Research Project 03-242/IA-43, which was financed by the Community of Castilla-La Mancha Council of Agriculture (Spain).

The authors wish to thank Joan Mart and Kathy Walsh for their assistance in translating the original text to English.
}

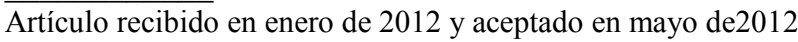

Artículo disponible en versión electrónica en la página www.revista-eea.net, ref. ə-30203 


\section{INTRODUCTION}

Consumer fear triggered by food scares and technological developments such as genetic modification and food irradiation, has resulted in a serious concern about food safety, and in a growing demand for quality assurance and additional information about production methods. Besides, as a result of public awareness of the irreparable damage done to the environment by practices leading to soil and water pollution, depletion of natural resources and destruction of delicate ecosystems, many voices have been raised demanding a more responsible attitude towards our natural heritage. With this background, organic farming, once seen as a fringe element intended to meet the needs of a particular sector of the market, has now come to the forefront as an agricultural approach which not only produces safe food, but also advocates a responsible attitude from an environmental viewpoint (European Commission 2009). At the same time, there is a growing awareness in the population of the relationship between health and food (Sánchez, Sanjuán and Akl, 2001).

Organic farming differs from other farming systems in several ways. This type of farming favours the use of renewable resources and recycling, returning nutrients present in waste products to the soil. Where livestock is concerned, it regulates production paying particular attention to animal welfare and the use of natural foodstuffs. Moreover, organic farming respects the environment's own system for controlling pests and disease in crops and livestock while avoiding, to a great extent, the use of pesticides, herbicides, chemical fertilisers, growth hormones, and antibiotics, thus contributing to sustainable ecosystems and a reduction in pollution.

In the last few years we have witnessed a significant development in this type of farming on a national as well as international level. This development is sometimes motivated by real growth and sometimes by improvement in the availability of information. In Spain, as well as in the rest of Europe and especially in the European Union ${ }^{1}$, the development of organic farming is on the rise in every aspect: surface area, number of farms, number of producers, and so on (Michelsen et al., 1999; Willer and Yussefi, 2007; MARM, 2009). Nevertheless, an increase in production from organic farming has not brought about a significant increase in consumption.

With the purpose of adapting to consumer needs, a number of studies which evaluate consumer attitudes to organic food have been carried out in various countries (Germany: Werner and Alvensleben, 1984; Alvensleben, 1998; the

\footnotetext{
${ }^{1}$ The organic market in the EU increased 5\% to 18.4 billion Euros in 2009, in spite of the economic crisis. Spain is the top country in the EU in terms of agricultural land for organics 1.33 million hectares, and it is considered the 9th largest market in the world for organic food consumption - 905 million Euros (Research Institute of Organic Agriculture, 2009).
} 
United Kingdom: Tregear, Dent and McGregor, 1994; Makatouni, 2002; Denmark: Grunert and Juhl, 1995; Ireland: Roddy, Cowan and Hutchinson, 1996; Norway: Wandel and Bugge, 1997; France: Robert-Kréziak, 1998; the Netherlands: Schifferstein and Oude Ophuis, 1998; Sweden: Shepherd, Magnusson and Sjöden, 2005; Italy: De Magistris and Gracia, 2008; Spain: Sánchez, Gil and Garcia, 1998a, Sánchez et al., 1998b; Brugarolas and Rivera 2001, Aguirre et al., 2003; Bernabéu et al., 2003, Brugarolas et al., 2008, Ureña, Bernabéu and Olmeda, 2008; and Greece: Zotos, Ziamou and Tsakiridou, 1999). In general, these studies have identified the importance of food safety, health, environmental concerns and better taste as principal factors promoting the purchase of organic food.

Specifically, the main attraction of these markets is centred on improved food safety (Huang, 1995), health (Beharrel and MacFie, 1991; Roddy, Cowan and Hutchinson, 1994; Robert-Kréziak, 1998; Schifferstein and Oude Ophuis, 1998; Chinnici, D'Amico and Pecorino, 2002; Chryssohoidis and Krystallis, 2005; Padel and Foster, 2005; Roitner-Schobesberger et al., 2008), quality (Haglund et al., 1999) and animal welfare (Fearne and Lavelle, 1996), as well as an increased respect for the environment (Cudjoe and Rees, 1992; Dufour and Loisel, 1996; Bigné, 1997; Roozen and De Pelsmaker, 1997; Wandel and Bugge, 1997; Haglund et al., 1999; Alampi et al., 2002; Fraj, Martinez and Montaner, 2004; Brugarolas et al., 2008). On the contrary, the factors that can limit consumption and even the presence of organic foods in certain distribution centres are basically related to the difficulty in guaranteeing a certain volume and homogenous quality as well as the existence of high prices (Marchesini, 1992; Briz et al., 1993; Hansen and Sorensean, 1993; Florkowski et al., 1994; Fox, 1996; Siikamäki, 1996; Sánchez et al., 1998a; Magnusson et al., 2001; Soler, Gil and Sánchez, 2002).

Considering the previous restrictions, some authors, based on demographic variables (Ling-Yee, 1997; Dubois and Rovira, 1999; Janda and Trocchia, 2001), have tried to analyse consumer behaviour which seems to present specific characteristics that should be known in order to propose commercial solutions that adjust to their requirements.

However, there now seems to be considerable agreement that demographic variables can hardly predict consumer behaviour, due to great differences in consumer behaviour within the same demographic criteria sector (Hustad and Pessemier, 1972). Even though the effects of demographic criteria on purchasing behaviour are statistically significant, the size of such effects is usually small (Hustad and Pessemier, 1974).

Lifestyle is understood as a series of guidelines on people's conduct according to the way they live, spend their money and use their free time (Mowen, 1987), in addition to their potential power as a segmentation criterion. 
In this sense, consumer behaviour based on lifestyle can also be used to develop advertising campaigns (Horn, 1991), to position and reposition the product (Wells, 1974) and even to develop the product (Grunert, Brunso and Bisp, 1993). On the other hand, consumer lifestyle can also be a useful criterion in standardising a global commercialisation strategy (Buzzell, 1968; Jain, 1989).

Attitude towards the environment seems to have special relevance in the lifestyle of the organic food consumer who consequently adjusts his purchasing behaviour. While some authors positively relate environmental problems to consumer behaviour towards organic food (Dispoto, 1977; Grunert and Rohme 1992; Park, Mothersbaugh, and Feick, 1994; Chan, 2001), others do not obtain significant results (Schahn and Holzer, 1990).

This paper aims to contribute to greater knowledge about Spanish consumers by analysing the degree of influence that various psychographic factors (lifestyle) have on the organic food consumer purchase attitude measured though expenditure and consumption, while simultaneously determining the degree of influence from environmental attitude.

\section{METHODOLOGY}

Information was obtained through a series of polls directed to a sample cross-section of habitual food purchasers, residing in Castilla-La-Mancha (Spain) (Figure 1). Polls were taken during the month of July 2002, based on a stratified random sample, from people on the point of make a purchase in shops, supermarkets and shopping centres, according to the population per agrarian region, gender and age. There were 463 surveys. Random sampling maximum error was less than 4.7 per cent with a confidence level of 95.5 per cent $(\mathrm{k}=2)$. Previous to field work, a preliminary questionnaire was given to 15 people who normally purchase groceries to confirm that the questions on the poll were welldesigned and understandable.

Figure 1

Castilla-La Mancha (Spain)

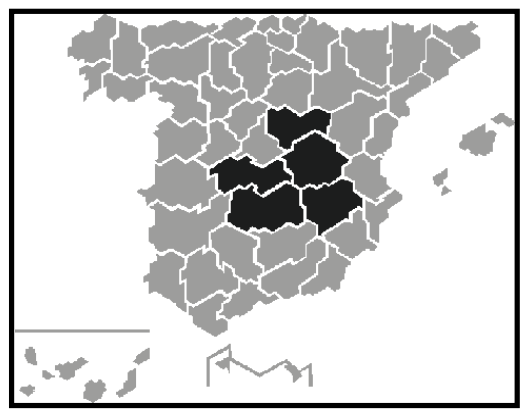

Source: National Statistics Institute (INE) 
Data analysis consisted of carrying out a multivariate analysis by means of Structural Equation Models (SEM), computed with the maximum likelihood method, using the Amos Graphics 17.0 Software Programme (SPSS, 2009). The causal relationship among data was studied with SEM by simultaneously integrating a series of different, but interdependent, multiple regression equations, since variables which are dependent in one relationship can be interdependent in another relationship within the same model (Hair et al., 1999; Barrio and Luque, 2000), and by incorporating a series of unobserved latent variables to the analysis.

With the object of obtaining an adequate sized sample, a sub-sample of those surveyed was selected who have an acceptable minimum level regarding what is considered organic food. Depending on the extent of agreement in relation to six objective knowledge items about organic foods (Annex 1) on a five-point balanced Likert scale ${ }^{2}(1$ being the strongest disagreement and 5 , the strongest agreement), those were selected who obtained over twenty points on a scale ranging from a minimum of six points to a maximum of thirty ${ }^{3}$. Thus, a subsample was obtained of 215 people (Annex 2), very close to the recommended value of 200 (Hoogland and Boomsma, 1998; Hair et al., 1999; Boomsma and Hoogland, 2001).

Attitude about buying organic food is the variable to be explained. As an explanatory variable, we use variables related to the knowledge of organic food and psychographic characteristics such as: values, lifestyle and attitudes towards the environment. Most of the variables integrated into the model can be considered latent, that is, formal representations of the latent construct in the model which cannot be directly observed. Bollen (1989) recommends giving a clear meaning to the concept to be measured, identifying the latent variables which represent it, contributing measurement indicators based on the previous theory and specifying the relationship between indicators or observable variables and concepts or latent variables.

In the first place, the models for measuring the different latent variables were analysed. To do so, the reliability of the scale used was studied by carrying out an exploratory factorial analysis (EFA) ${ }^{4}$, which allows for the identification of the different factors. Afterwards, a confirmatory factorial analysis (CFA) was

\footnotetext{
${ }^{2}$ Previous studies advised reducing the number to five categories due to interviewed individuals' low degree of knowledge about survey items (Grande \& Abascal 2000).

${ }^{3}$ The generic problem with "organic foods" is that the term organic is often confused with green, ecological, environmental, natural, sustainable and others (Aarset et al. 2004). The selection was made with the object of identifying consumers with a greater knowledge about organic foods

${ }^{4}$ Its objective is to define possible relationships only generally, leaving verification of prespecified relationships to confirmatory factorial analysis (CFA).
} 
carried out with the purpose of evaluating the convergent as well as the discriminate validity.

The scale used is that proposed by Sánchez et al. (1998b). This scale has 23 indicators (variables), 15 to measure lifestyle and 8 to measure attitude towards the environment. All of these are measured on a 5-point Likert scale (1 being the strongest disagreement and 5, the strongest agreement). These indicators were also related to the organic food purchase attitude measured though monthly expenditure ${ }^{5}$ (OFE) and consumption (occasional, habitual) (OFC).

Finally, parameters for diagnosis of the model were: the Chi-square $\left(\chi^{2}\right)$, the root mean square error of approximation (RMSEA), the goodness of fit index (GFI), the adjusted goodness of fit index (AGFI) and the comparative fit index (CFI) (Schermelleh-Engel, Moosbrugger and Müller, 2003).

\section{RESULTS}

On Table 1 consumer responses to the 15 lifestyle-related indicators are analysed. The aspects valued most by those surveyed are: frequent consumption of fruit and vegetables, with an average of 3.97 on a 5-point scale; balance between private life and work, with an average of 3.61; and restriction of salt intake, with an average value of 3.54. Lifestyles with the lowest marks belong to members of Nature conservation associations, with an average of 1.29; collaborators of non-profit organizations, with an average of 1.63; and adherents to a vegetarian diet, with an average of 2.00 .

Next, the reliability of the scale was analysed through its internal consistency. A Cronbach Alpha ${ }^{6}$ (Peterson, 1994) value of 0.78 was obtained, which is considered acceptable since it exceeds the value of 0.7 (Hair et al., 1999; Grande and Abascal, 2000).

Then, an EFA of the principal components and a Varimax rotation were made (Kaiser, 1958), resulting in four factors which explain 52.56 per cent of the variance. The first factor, called balance here, shows the consumer as balanced and methodical in his behaviour. This factor consists of "Lead an orderly methodical life" (TML), "Balance private life and work" (BPLW), Try to reduce stress (TRS) and "Visit the dentist regularly" (VDR) variables, and explains 24.93 per cent of the variance. The second factor, diet, shows concern for food related matters and food safety, and explains 10.43 per cent of the variance. The third factor, active, shows collaboration and integration in matters concerning Nature conservation. It explains 9.35 per cent of the variance.

\footnotetext{
${ }^{5}$ The scale of monthly expenditure considered was: $15 €$ and under, from 15.01 to $30 €$, from 30.01 to $60 €$, from 60.01 to $120 €$, and over $120 €$.

${ }^{6}$ Measurement of habitually used reliability with regard to a set of the two or more construct indicators. Values range from 0 to 1 .
} 
Lastly, the fourth factor, health, shows the degree of concern regarding health. This factor explains 7.85 per cent of the variance (Table 1).

Table 1

Descriptive statistics and factorial analysis corresponding to lifestyle

\begin{tabular}{|c|c|c|c|c|c|c|}
\hline \multicolumn{3}{|c|}{ Descriptive statistics } & \multicolumn{4}{|c|}{ Factorial analysis } \\
\hline Attitudes & Mean & SD* & $\begin{array}{l}\text { Factor } 1 \\
\text { Balance }\end{array}$ & $\begin{array}{c}\text { Factor } 2 \\
\text { Diet }\end{array}$ & $\begin{array}{l}\text { Factor } 3 \\
\text { Active }\end{array}$ & $\begin{array}{c}\text { Factor } 4 \\
\text { Health }\end{array}$ \\
\hline $\begin{array}{l}\text { Lead an orderly methodical life } \\
\text { (TML) }\end{array}$ & 3.37 & \pm 1.17 & 0.809 & 0.192 & 0.029 & 0.080 \\
\hline $\begin{array}{l}\text { Balance private life and work } \\
\text { (BPLW) }\end{array}$ & 3.61 & \pm 1.20 & 0.766 & 0.165 & 0.230 & -0.164 \\
\hline Try to reduce stress (TRS) & 3.17 & \pm 1.20 & 0.660 & 0.146 & 0.013 & 0.197 \\
\hline Visit the dentist regularly (VDR) & 2.55 & \pm 1.32 & 0.476 & -0.174 & 0.179 & 0.446 \\
\hline $\begin{array}{l}\text { Eat fruit and vegetables regularly } \\
\text { (FVR) }\end{array}$ & 3.97 & \pm 0.98 & 0.164 & 0.746 & 0.045 & -0.021 \\
\hline Avoid industrialized food (AIF) & 2.92 & \pm 1.19 & 0.074 & 0.589 & 0.233 & 0.324 \\
\hline Eat red meat moderately (RMM) & 3.44 & \pm 1.21 & 0.066 & 0.582 & 0.061 & -0.027 \\
\hline Restrict salt intake (RSI) & 3.54 & \pm 1.32 & 0.088 & 0.542 & -0.148 & 0.444 \\
\hline Eat food with no additives (FNA) & 2.69 & \pm 1.13 & 0.289 & 0.464 & 0.381 & 0.265 \\
\hline $\begin{array}{l}\text { Collaborate with non-profit } \\
\text { organizations (NPO) }\end{array}$ & 1.63 & \pm 1.19 & 0.160 & 0.101 & 0.693 & -0.016 \\
\hline $\begin{array}{l}\text { Belong to a nature conservation } \\
\text { association (NCA) }\end{array}$ & 1.29 & \pm 0.81 & -0.106 & -0.020 & 0.632 & 0.306 \\
\hline Read food labels (RFL) & 3.17 & \pm 1.31 & 0.213 & 0.157 & 0.626 & -0.166 \\
\hline Exercise regularly (ER) & 2.78 & \pm 1.38 & 0.011 & 0.009 & 0.526 & 0.406 \\
\hline Follow a vegetarian diet (FVD) & 2.00 & \pm 1.20 & -0.098 & 0.207 & 0.142 & 0.711 \\
\hline $\begin{array}{l}\text { Go for voluntary medical check-ups } \\
\text { (VMC) }\end{array}$ & 2.56 & \pm 1.38 & 0.308 & 0.080 & 0.011 & 0.631 \\
\hline Explained variance-Factor (\%) & & & 24.935 & 10.428 & 9.355 & 7.847 \\
\hline Accumulated explained variance (\%) & & & 24.935 & 35.362 & 44.718 & 52.565 \\
\hline Sample adequation (Kaiser-Meyer-O & & & & & & 0.776 \\
\hline Cronbach Alpha & & & & & & 0.780 \\
\hline \multirow{3}{*}{ Bartlett roundness test } & \multicolumn{2}{|c|}{ Chi-square } & & & & $1,319.48$ \\
\hline & \multicolumn{2}{|c|}{ Degrees of freedom } & & & & 105 \\
\hline & \multicolumn{2}{|c|}{ Significance level } & & & & 0.000 \\
\hline
\end{tabular}

* SD: Standard Deviation

Source: Own elaboration.

After the previous analysis, a CFA was carried out to evaluate converging validity, verifying that standardized weights (SW) and critical ratio (CR) exceeded the minimum recommended levels of 0.4 and 1.96 respectively, except for the VDR and RMM indicators, which also present low reliability $(\mathrm{R})$. That is, they represent reduced common variance between the indicator and the latent 
variable. Successive calculations recommended eliminating the RSI and RFL indicators, in addition to the two aforementioned indicators, as well as the health factor.

In relation to attitude about the environment (Table 2), people who think that our current civilization is destroying Nature obtained the highest marks, with 4.47 out of 5 points. In second place were those who think that if nothing is done, the damage will be irreversible. The lowest marks belong to positive attitudes with regard to collaboration with environmental protection, with 2.56 points, and to those who consider agricultural activities a great pollutant, with 2.97 points.

Table 2

Descriptive statistics and factorial analysis of attitudes towards environment

\begin{tabular}{|c|c|c|c|c|c|}
\hline \multicolumn{3}{|l|}{ Descriptive statistics } & \multicolumn{3}{|c|}{ Factorial analysis } \\
\hline Attitudes & Mean & SD* $^{*}$ & $\begin{array}{c}\text { Factor } 1 \\
\text { Individual } \\
\text { Awareness } \\
\end{array}$ & $\begin{array}{c}\text { Factor } 2 \\
\text { Social } \\
\text { Awareness } \\
\end{array}$ & $\begin{array}{c}\text { Factor } 3 \\
\text { Business } \\
\text { Awareness } \\
\end{array}$ \\
\hline $\begin{array}{l}\text { I am concerned about the consequences of } \\
\text { human activity on climatic changes (HACC) }\end{array}$ & 3.20 & \pm 1.09 & 0.829 & 0.221 & -0.073 \\
\hline $\begin{array}{l}\text { I collaborate with environmental care } \\
\text { related activities (CEC) }\end{array}$ & 2.56 & \pm 1.31 & 0.811 & -0.103 & 0.143 \\
\hline I prefer using recycled goods (PRG) & 3.44 & \pm 1.16 & 0.510 & 0.411 & 0.296 \\
\hline $\begin{array}{l}\text { I throw rubbish in selective containers } \\
\text { (organic, non-organic, batteries) (RSC) }\end{array}$ & 3.78 & \pm 1.32 & 0.487 & 0.464 & 0.215 \\
\hline $\begin{array}{l}\text { Current civilization is destroying Nature } \\
\text { (CDN) }\end{array}$ & 4.47 & \pm 0.80 & 0.102 & 0.793 & -0.050 \\
\hline $\begin{array}{l}\text { If nothing is done, the damage to the } \\
\text { environment will be irreversible (DEI) }\end{array}$ & 4.55 & \pm 0.70 & 0.045 & 0.770 & 0.101 \\
\hline $\begin{array}{l}\text { Nature Preservation is another way for } \\
\text { businesses to increase sales (NPBS) }\end{array}$ & 3.40 & \pm 1.11 & 0.015 & -0.033 & 0.830 \\
\hline $\begin{array}{l}\text { I believe agricultural activities are a great } \\
\text { pollutant for the environment (AAP) }\end{array}$ & 2.97 & \pm 1.30 & 0.150 & 0.142 & 0.712 \\
\hline \multicolumn{3}{|l|}{ Explained variance-Factor (\%) } & 33.400 & 14.840 & 13.420 \\
\hline \multicolumn{3}{|l|}{ Accumulated explained variance (\%) } & 33.400 & 48.240 & 61.660 \\
\hline \multicolumn{3}{|l|}{ Sample adequation (Kaiser-Meyer-Olkin) } & & & 0.735 \\
\hline \multicolumn{3}{|l|}{ Cronbach Alpha } & & & 0,700 \\
\hline \multirow{3}{*}{ Bartlett roundness test } & \multicolumn{2}{|l|}{ Chi-square } & & & 274.604 \\
\hline & \multicolumn{2}{|c|}{ Degrees of freedom } & & & 28 \\
\hline & \multicolumn{2}{|c|}{ Significance level } & & & 0.000 \\
\hline
\end{tabular}

* SD: Standard Deviation

Source: Own elaboration. 
Next the reliability of the scale by means of its internal consistency was analysed, obtaining a Cronbach Alpha value of 0.7, equal to the minimum recommended value.

Immediately afterwards, an EFA of the principal components and a Varimax rotation were carried out, extracting three factors which explain 61.66 per cent of the variance. The first factor explains 33.40 per cent; the second factor, 14.84 per cent; and the third factor, 13.42 per cent. The variables which make up each factor are shown on Table 2, as well as the Kaiser-Meyer-Olkin (KMO) sample adequation measurement and the Bartlett roundness test.

The first factor was called individual awareness since the individual aspects related to the environment such as separating rubbish and buying recycled goods, were predominant. The second factor, social awareness, was so named due to the collective feeling that our current civilization will irreversibly deteriorate the environment if no action is taken. The third factor is directly related to businesses or industries and it considers farming a pollutant. So this factor was named business awareness.

The KMO sample adequation measurement is 0.735 , which is considered adequate (0.5). Moreover, Bartlett's roundness test obtained significant results.

After the previous analysis, a CFA was made and the NPBS variable was eliminated due to its low reliability, which led to the elimination of the business awareness factor, leaving the definite scale with two factors. The CEC variable was maintained with the object of having three indicators, in spite of their low reliability.

\section{Figure 2}

Model sequence diagram

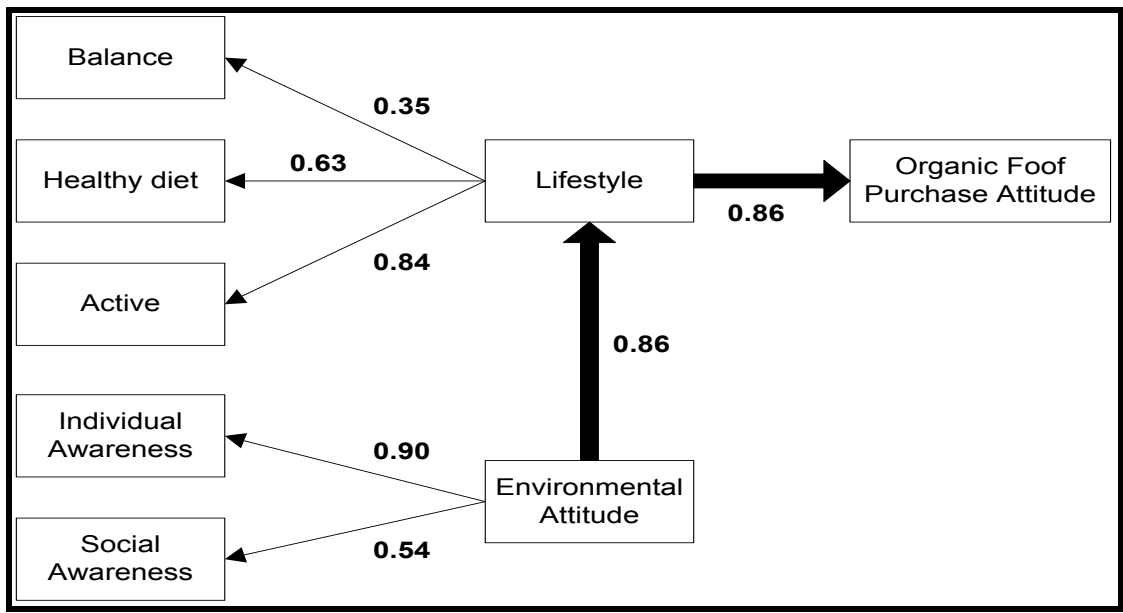

Source: Own elaboration. 
Once the measuring scales were evaluated, the proposed global model was analysed. Figure 2 shows the sequence diagram global model after verifying that the model is correctly specified and that there are no identification problems.

\section{DISCUSSION}

As Figure 2 comprehensively shows, attitudes towards buying organically produced foods, measured by organic food monthly expenditure (OFE) and consumption (OFC), are closely related to consumer lifestyles and are influenced by their own environmental attitudes. This shows that Spanish consumers behave similarly to what Ellen, Wiener and Cobb-Walgren (1991) described, that favouring improvement of the environment was a significant predictor for purchasing environmentally safe products and for recycling activities. Schwepker and Cornwell (1991) also linked consumer intentions of purchasing packaged organic products to environmental attitudes and behaviour. Milton and Rose (1997) found that consumer attitudes toward the environment were a good predictor of intentions to act in environmentally concerned ways. All this leads to consider that the critical variable for standardisation of a global commercialisation strategy (Buzzell, 1968; Jain, 1989) in relation to organic food purchase, is consumer environmenttal attitude.

This environmental attitude is in turn determined by the degree of awareness due to a positive relationship between consumer behaviour towards organic food and towards environmental problems, as detected by other authors (Dispoto, 1977; Grunert and Rohme, 1992; Park et al., 1994; Kleijn et al., 1995; Polonsky and Mintu-Wimsatt, 1995; Dufour and Loisel, 1996; Wandel and Bugge, 1997; Chan, 2001). On the contrary Robert-Krèziak (1998) and Schifferstein and Oude Ophuis (1998) consider that the main determinant towards purchase attitude is health, whereas other authors consider the main determinants are information (Aaron, Mela and Evans, 1994), origin (Johansson et al., 1999) and taste (Sjöberg, 1996; Grankvist and Biel, 2001; Magnusson et al., 2001). However, it is necessary to realise that a generally positive attitude towards an organically produced product does not imply the choice or purchase of that product (Magnusson et al., 2001).

Therefore, in our model, consumer attitude towards purchasing organic food is directly related to lifestyle (determined as well by degree of activity, importance of diet on health and a balanced life), which seems to act as a support to influence environmental attitude.

In order to validate the structural equation models, three types of fit quality measures were used: absolute, incremental and parsimony fit measures:

a) Among the absolute fit measures, the chi-square value of 168.445 with 99 degrees of freedom proves to be statistically significant. The noncentrality 
parameter $(\mathrm{NCP}=69.445)$ is equal to the difference between chi-square and the degrees of freedom and is used to compare alternative models. The Goodness of Fit Index (GFI=0.909) represents total degree of fit, comparing predicted squared residuals with effective data, fluctuating between 0 (bad fit) and 1.0 (perfect fit) (Hair et al., 1999). The root mean square error of approximation (RMSEA $=0.057$ ) measures discrepancy per degree of freedom in terms of population. Values between 0.05 and 0.08 are considered acceptable (Brown and Cudeck, 1989).

b) Incremental fit measures compare the model with a null model. The null model has a chi-square value of 660.548 with 120 degrees of freedom, with a reduction of the chi-square value of 492.103. The Tucker-Lewis index $(\mathrm{TLI}=0.844)$ and the normed fit index $(\mathrm{NFI}=0.745)$ are below the recommended 0.9 level. The NFI index evaluates the decrease in the adopted model's statistical chi-squared with regard to the base model. According to Batista and Coenders (2000) this index is not advisable since, by not taking degrees of freedom into account, it favours the adoption of overparametrised models, because the index always increases when parameters are added to the model.

c) Parsimony fit measures relate model goodness-of-fit to the number of estimated coefficients required to obtain this fit level. The normed chi-square obtained (1.702) falls within recommended levels. The parsimony normed fit index (PNFI $=0.615)$ is close to admissible levels.

In general, adjustment of the model can be considered acceptable (Schermelleh-Engel, Moosbrugger and Müller, 2003).

\section{CONCLUSIONS}

Organic food purchase attitude is directly related to consumer lifestyle and is influenced by consumer environmental attitude as well. In this sense, lifestyle and environmental attitude act positively on consumer organic food purchasing attitude.

Consumer characteristics that seem to determine lifestyle, are people who are methodical in their way of life, who balance their work schedule with time for their family and who would most probably not sacrifice their free time in order to make more money (Balance), concern about the effects that nutrition and diet have on health (Healthy diet) and collaboration or membership in Nature conservation or related groups (Active).

Consumer environmental attitude is determined when individually, they recycle products, collaborate in environmental activities and are concerned about the consequences of human productive activity on Nature (Individual Awareness) and socially, they consider that our present civilization is contributing to 
the destruction of Nature, which if not stopped, will be irreversible (Social Awareness).

Therefore, it can be concluded that any enterprise strategy aimed at fomenting organic food consumption must have the environmental variable as its communication axis, which seems to be more effective when it affects the above-mentioned characteristics of consumer lifestyle.

Finally, this research is situated along the line of other papers that consider environmental attitude as the main organic food consumer attitude, versus those that consider it to be health. However, this research differs from other papers that consider environmental attitude as the main determinant directly affecting purchase attitude, since this research does so indirectly through consumer lifestyle.

In this sense at least, the present paper is novel, in its application to the Spanish market and in line with research from other countries on organic food that use the methodology of Structural Equation Models, instead of sociodemographic variables. At the same time we believe, just as Buzzell (1968) and Jain (1989) indicate, that consumer lifestyle can be a useful criterion for standardising organic food commercialisation parameters in a global marketing strategy, at least in the case of Spain.

\section{REFERENCES}

AARON, J.I.; MELA, D.J. y EVANS, R.E. (1994). "The influences of attitudes, beliefs and label information on perceptions of reduced-fat spread". Appetite, 22(1), pp. 25-37.

AARSET, B.; BECKMANN, S.; BIGNÉ, E.; BEVERIDGE, M.; BJORNDAL, T.; BUNTING, J. MCDONAGH, P., MARIOJOULS, C., MUIR, J., PROTHERO, A., REISCH, L., SMITH, A.; TVETERAS, R. y YOUNG, J. (2004). "The European consumers' understanding and perceptions of the "organic" food regime". British Food Journal, 106(2), pp. 93-105.

AGUIRRE, M.S.; ALDAMIZ-ECHEVARRIA, C.; CHARTERINA, J. y VICENTE, A. (2003). "El consumidor ecológico: un modelo de comportamiento a partir de la recopilación y análisis de la evidencia empírica". Distribución y Consumo, 67, pp. 41-53.

ALAMPI, V.; CONTINI, C.; MARTINI, A. y MENGHINI, S. (2002). "Possible development of organic production in a mountain area of the Florence province in Tuscany". British Food Journal, 104(8), pp. 654-669.

ALVENSLEBEN, R.V. (1998). "Ecological aspects of food demand: the case of organic food in Germany". AIR-CAT 4th Plenary Meeting: Health, Ecological 
and Safety Aspects in Food Choice 4, AIR-CAT, MATFORSK., As, Norway, pp. 68-79

BARRIO, S. y LUQUE, T. (2000). “Análisis de ecuaciones estructurales”. En T. Luque (ed.): Técnicas de análisis de datos en investigación de mercados (pp. 489-557). Madrid. Pirámide.

BATISTA, J.M. y COENDERS, G. (2000). Modelos de Ecuaciones Estructurales. Cuadernos de estadística. Madrid. La Muralla.

BEHARREL, B. y MACFIE, J.H. (1991). "Consumer attitudes to organic foods". British Food Journal, 93(2), pp. 25-30.

BERNABÉU, R.; OLMEDA, M.; CASTILLO, S.; FABEIRO, C. y UREÑA, F. (2003). "Estructura de preferencias de los consumidores de alimentos ecológicos en Castilla-La Mancha”. Actas del V Coloquio Hispano-Portugués de Estudios Rurales. Bragança (Portugal). Disponible en: http://www.esa.ipb.pt/estudosrurais [Último acceso el 22 de enero de 2004].

BIGNÉ, J.E. (1997). "El consumidor verde: bases de un modelo de comportamiento". Esic Market, 96, pp. 29-43.

BOLLEN, K.A. (1989). Structural Equations with latent variables. New York. John Wiley \& Sons, Inc.

BOOMSMA, A. y HOOGLAND, J.J. (2001). "The robustness of LISREL modelling revisited". En R. Cudeck, S. Du Toit and D. Sörbom (ed.): Structural equations models: Present and future. A Festschrift in honor of Karl Jöreskog. Scientific Software International (pp. 139-168). Chicago.

BRIZ, J.; MAHLAU, M.; UZCANGA, M. y ÁLVAREZ, M.J. (1993). "Comercialización de productos ecológicos: consideraciones de un estudio a nivel detallista en España". Revista de Estudios AgroSociales, 164, pp. 129-140.

BROWNE, M.W. y CUDECK, R. (1989). "Single Sample cross-validation indices for covariance structures". Multivariate Behavioral Research, 34, pp. 445455.

BRUGAROLAS, M. y RIVERA, L.M. (2001). “Comportamiento del consumidor valenciano ante los productos ecológicos integrados". Revista de Estudios Agrosociales y Pesqueros, 192, pp. 105-121.

BRUGAROLAS, M.; BERNABÉU, R.; MARTÍNEZ-POVEDA A.; MARTÍNEZCARRASCO, L. y DÍAZ, M. (2008). "Herramientas para la aceptación de un vino ecológico: Health claims and green claims". International Organisation of Vine and Wine. Communication presented in the XXXIst World Congress of Vine and Wine. Verona, Italia, June 15-20.

BUZZELL, R.D. (1968). “Can you standardize multinational marketing?". Harvard Business Review, 6, pp. 102-113.

CHAN, R.Y.K. (2001). “Determinants of Chinese Consumer's Green Purchase Behavior". Psychology and Marketing, 18(4), pp. 289-413.

CHINNICI, G., D'AMICO, M. y PECORINO, B. (2002). "A multivariate statistical analysis on the consumers of organic products". British Food Journal, 104(3), pp. 187-199. 
CHRYSSOHOIDIS, G.M. y KRYSTALLIS, A. (2005). "Organic consumers' personal values research: testing and validating the list of values, LOV scale and implementing a value-based segmentation task". Food Quality and Preference 16, pp. 585-599.

CUDJOE, F. y REES, P. (1992). "How important is organic farming in Great Britain?". Tijdschrift voon Econ. Soc. Geografie, 83(1), pp. 13-24.

DE MAGISTRIS, T. y GRACIA A. (2008). "The decision to buy organic food products in Southern Italy". British Food Journal 110(9), pp. 929-947.

DISPOTO, R.G. (1977). "Interrelationships among measures of environmental activity, emotionality and knowledge". Educational and Psychological Measurement, 37, pp. 451-459.

DUBOIS, B. y ROVIRA, A. (1999). Comportamiento del consumidor. Comprendiendo al consumidor. Madrid. Prentice-Hall,

DUFOUR, A. y LOISEL, J.P. (1996). Les opinions des français sur l'environnement et sur la forêt. Collection Études et Travaux, 12, CREDOC, Paris.

ELLEN, P.S.; WIENER, J.L. y COBB-WALGREN, C. (1991). "The role of perceived consumer effectiveness in motivating environmentally conscious behaviours". Journal of Public Policy and Marketing, 10, pp. 102-117.

EUROPEAN COMMISSION (2009). "Agricultura ecológica". Disponible en: http://ec.europa.eu/agriculture/organic/organic-farming_es [Último acceso el 17 de Julio de 2009].

FEARNE, A. y LAVELLE, D. (1996). "Segmenting the UK egg market: results of a survey of consumer attitudes and perceptions". British Food Journal, 98(1), pp. 7-12.

FLORKOWSKI, W.J.; HALBRENDT, C.; HUANG, CH.L. y STERLING, L. (1994). "Socioeconomic determinants of attitudes toward bioengineered products". Review of Agricultural Economics, 16(1), pp. 125-132.

FOX, J.A. (1996). "The use of experimental methods in consumer preference studies". IX EAAE Congreso, Edinburgh, UK.

FRAJ, E.; MARTÍNEZ, E. y MONTANER, T. (2004). "La compra de productos ecológicos explicada a través de las características psicográficas del consumidor". XIV Congreso ACEDE. Murcia 2004. Disponible en: http://www.acede.org/index_archivos/CDMurcia/Indice\%20de\%20Autores/do cumentos/ldP414.pdf. [Último acceso el 30 de enero de 2008].

GRANDE, I. y ABASCAL, E. (2000). Fundamentos y Técnicas de Investigación Comercial. ESIC, Madrid.

GRANKVIST, G. y BIEL, A. (2001). "The importance of beliefs and purchase criteria in the choice of eco-labelled food products". Journal of Environmental Psychology, 21(4), pp. 405-410.

GRUNERT, K.G.; BRUNSO, K. y BISP, S. (1993). "Food-related life style: Development of a cross-culturally valid instrument for market surveillance". MAPP Working Paper, No. 12. 
GRUNERT, S. y RÖHME, N. (1992). "Consumer's environmental concern: Are we really tapping true concern that relates to environmentally ethic behavior?" ESOMAR Conference on Marketing and Research under a New World Order, Tokyo.

GRUNERT, S.C. y JUHL, H.J. (1995). "Values, environmental attitudes and buying of organic foods". Journal of Economic Psychology, 16(1), pp. 39-62.

HAGLUND, A.; JOHANNSON, L.; BERGLUND, L. y DAHLSTEDT, L. (1999). "Sensory evaluation of carrots from ecological and conventional growing systems". Food Quality and Preference, 10(2), pp. 23-29.

HAIR, J.; ANDERSON, E.; TATHAN, R. y BLACK, W. (1999). Análisis Multivariante. Madrid. Prentice Hall.

HANSEN, J.K. y SORENSEAN, H.G. (1993). "The importance of price for the sale of ecological products". MAPP Working Paper, No. 13.

HORN, M. (1991). "How life-style research is conducted at DDB Needham". Paper presented at the 1st EIASM Workshop on Value and Life style Research in Marketing, Brussels.

HOOGLAND, J.J. y BOOMSMA, A. (1998). "Robustness Studies in Covariance Structure Modelling". Sociological Methods and Research, 26, pp. 329-367.

HUANG, C.L. (1995). "Consumer preferences and attitudes towards organically grown produce". European Review of Agricultural Economics, 23(3), pp. 331-342.

HUSTAD, T.P. y PESSEMIER, E.A. (1972). "Industry's use of life style analysis: Segmenting consumer market with activity and attitude measures". En F.D. Allvine (ed.): American Marketing Association, Combined Proceedings (pp. 296-301). Chicago.

HUSTAD, T.P. y PESSEMIER, E.A. (1974). "The Development and Application of Psychographic Life Style and Associated Activity and Attitude Measures". En W.D. Wells (ed.): American Marketing Association (pp. 31-70), Chicago.

JAIN, S.C. (1989). "Standarization of international marketing strategy: Some research hypotheses". Journal of Marketing, 53(1), pp. 70-79.

JANDA, S. y TROCCHIA, P. (2001). "Vegetarianism: Toward a Greater Understanding". Psychology and Marketing, 18(12), pp. 1205-1240.

JOHANSSON, L.; HAGLUND, A.; BERGLUND, L.; LEA, P. y RISVIK, E. (1999). "Preference for tomatoes affected by sensory attributes and information about growth conditions". Food Quality and Preference, 10(4-5), pp. 289298.

KAISER, H.F. (1958). "El criterio del varimax para la rotación analítica en análisis factorial”. Psychometrika, Vol. XXIII, pp. 187-200.

KLEIJN, E.H.J.M.; BORGSTEIN, A.; DE JAGER, M.D. y ZIMMERMANN, H.K.L. (1995). "Enlarging the market for horticultural organics in the Netherlands". Acta Horticulturae, 391, pp. 143-151. 
LING-YEE, L. (1997). "Effect of Collectivist Orientation and Ecological Attitude on Actual Environmental Commitment: The Moderating Role of Consumer Demographics and Product Involvement". Journal of International Consumer Marketing, 9(4), pp. 31-53.

MAGNUSSON, M.K.; ARVOLA, A.; HURSTI, U-K.K.; ABERG, L. y SJÖDÉN, P.-O. (2001). "Attitudes towards organic foods among Swedish consumers". British Food Journal, 103(3), pp. 209-227.

MAKATOUNI, A. (2002). "What motivates consumers to buy organic food in the UK?" British Food Journal, 104, pp. 345-352.

MARCHESINI, L. (1992). "La relazione domanda prezzo nei prodotti dell'agricoltura ecologica". Rivista di Economia Agraria, 47(1), pp. 35-65.

MARM (2009). "Estadísticas 2008. Agricultura Ecológica. España. Ministerio de Medio Ambiente, y Medio Rural y Marino". Disponible en: http://www.mapa.es/ alimentacion/pags/ecologica/pdf/2008.pdf [Último acceso 22 de julio de 2009].

MICHELSEN, J.; HAMM, U.; WYNEN, E. y ROTH, E. (1999). "The European Market for Organic Products: Growth and Development". En S. Dabbert, N. Lampkin, J. Michelsen, H. Nieberg and R. Zanoli (ed.): Organic farming in Europe: Economics and policy. Universität Hohenheim/Institut für Landwirtschaftliche Betriebslehre 410A.

MILTON, A.P. y ROSE, R.L. (1997). "The effects of environmental concern on environmentally friendly consumer behaviour: an exploratory study". Journal of Business Research, 40, pp. 37-48.

MOWEN, J.C. (1987). Consumer behaviour. New York. Macmillan Publishing Company.

NATIONAL STATISTICS INSTITUTE (INE) (2002). "Demografía y población". Disponible en: http://www.ine.es/inebmenu/mnu_cifraspob.htm [Último acceso el 20 de noviembre 2011].

PADEL, S. y FOSTER, C. (2005). "Exploring the gap between attitudes and behaviour. Understanding why consumers buy or do not buy organic food". British Food Journal 107, pp. 606-625.

PARK, C.W., MOTHERSBAUGH, D.L. y FEICK, L. (1994). "Consumer knowledge assessment". Journal of Consumer Research, 21, pp. 71-82.

PETERSON, R.A. (1994). "A meta-analysis of Cronbach's coefficient alpha". Journal of Economic Research, 21, pp. 363-389.

POLONSKY, M.J. y MINTU-WIMSATT, A.T. (1995). Environmental Marketing, Strategies, Practice, Theory and Research. New York. The Haworth Press.

RESEARCH INSTITUTE OF ORGANIC AGRICULTURE (2009). Disponible en: http://www. fibl.org/en.html [Último acceso 20 de noviembre 2011].

ROBERT-KRÉZIAK, D. (1998). Les motivations de la consommation verte: Une approche par les chaînages cognitifs. Doctoral thesis, Université de Grenoble. 
RODDY, G.; COWAN, C. y HUTCHINSON, G. (1994). "Organic food: a description of the Irish market". British Food Journal, 96(4), pp. 3-10.

RODDY, G.; COWAN, C.A. y HUTCHINSON, G. (1996). "Consumer attitudes and behaviour to organic foods in Ireland". Journal of International Consumer Marketing, 9(2), pp. 41-63.

ROITNER-SCHOBESBERGER, B.; DARNHOFER, I.; SOMSOOK, S. y VOGL C.R. (2008). "Consumer perceptions of organic food in Bangkok, Thailand". Food Policy 33, pp. 112-121.

ROOZEN, I.T.M. y DE PELSMAKER, P. (1997). "Consumer's perception of a green consumption behaviour". 26th European Marketing Association Congress. Warwick Business School.

SÁNCHEZ, M.; GIL, J.M. y GRACIA, A. (1998a). "Frenos al crecimiento del mercado ecológico: ¿el precio o la actitud hacia el medio ambiente?" Revista Española de Investigación en Marketing, 3, pp. 103-116.

SÁNCHEZ, M.; GRANDE, I., GIL; J.M. y RODRÍGUEZ, A. (1998b). "Evaluación del potencial de mercado de los productos de agricultura ecológica”. Revista Española de Investigación en Marketing, 2, pp. 135-150.

SÁNCHEZ, M.; SANJUÁN, A. y AKL, G. (2001). "El distintivo de calidad como indicador de seguridad alimenticia en carne de vacuno y cordero". Revista de Economía Agraria y Recursos Naturales, 1(1), pp. 77-94.

SCHAHN, J. y HOLZER, E. (1990). „Studies of individual environmental concern: The role of knowledge, gender and background variables". Environment and Behavior, 22, pp. 767-786.

SCHERMELLEH-ENGEL, K.; MOOSBRUGGER, H. y MÜLLER, H. (2003). "Evaluating the Fit of Structural Equation Models: Tests of Significance and Descriptive Goodness-of-Fit Measures". Methods of Psychological Research, 8(2), pp. 23-74.

SCHIFFERSTEIN, H. y OUDE OPHUIS, P. (1998). "Health-related determinants of organic food consumption in the Netherlands". Food Quality and Preference, 9(3), pp. 119-133.

SCHWEPKER, C.H.JR. y CORNWELL, T.B. (1991). "An Examination of Ecologically Concerned Consumers and their Intention to Purchase Ecologically Packaged Products". Journal of Public Policy and Marketing, 10, pp. 77-101.

SHEPHERD, R.; MAGNUSSON, M. y SJÖDÉN P. (2005). "Determinants of consumer behaviour related to organic foods." Ambio, 34, pp. 4-5, June 2005.

SIIKAMÄKI, J. (1996). "Consumer preferences for using pesticide sin agriculture - a contingent valuation approach". IX EAAE Congress, Edinburgh, UK.

SJÖBERG, L. (1996). "Kost och hälsa-riskuppfattningar och attityder. Resultat av en enkätunder-sökning". Livsmedelsverket (National Food Administration), Uppsala (Sweden): pp. 26-29. 
SOLER, F.; GIL, J.M. y SÁNCHEZ, M. (2002). "Consumers' acceptability of organic food in Spain: Results from an experimental auction market". British Food Journal, 104(8), pp. 670-687.

SPSS, Inc. (2009). SPSS Categories. Version 17.0, Chicago.

TREGEAR, A., DENT, J.B. y MCGREGOR, M.J. (1994). "The demand for organically-grown produce". British Food Journal, 96(4), pp. 21-25.

WANDEL, M. y BUGGE, A. (1997). "Environmental concern in consumer evaluation of food quality". Food Quality and Preference, 8(1), pp. 19-26.

WELLS, W.D. (1974). "Life style and psychographics: Definitions, uses and problems". American Marketing Association, Chicago, pp. 317-363.

WERNER, J. AND ALVENSLEBEN, R.V. (1984). „Consumer attitudes towards organic food" in Germany. Acta Horticulturae, 155, pp. 221-227.

WILLER, H. y YUSSEFI M. (2007). "The world of organic agriculture. Statistics and emerging trends 2007. International Federation of Organic Agriculture Movements IFOAM". Disponible en: http://orgprints.org/10506/03/willeryussefi-2007-world-of-organic.pdf [Último acceso 18 de noviembre de 2009].

UREÑA F.; BERNABÉU R. y OLMEDA M. (2008). "Women, men and organic food: differences in their attitudes and willingness to pay. A Spanish case study". International Journal of Consumer Studies 32(1), pp. 18-26.

ZOTOS, Y.; ZIAMOU, P.L. y TSAKIRIDOU, E. (1999). "Marketing Organically Produced Food Products in Greece". Greener Management International, 25, pp. 91-104. 


\section{Annex 1}

The organic foods....

Value these items from 1 (strongly disagree) to 5 (strongly agree)

\begin{tabular}{|c|c|c|c|c|c|}
\hline Organic foods are: & $\begin{array}{l}\text { Strongly } \\
\text { disagree } \\
\text { (1) }\end{array}$ & $\begin{array}{c}\text { Disagree } \\
\text { (2) }\end{array}$ & $\begin{array}{l}\text { Indifferent } \\
\text { (3) }\end{array}$ & $\begin{array}{l}\text { Agree } \\
\text { (4) }\end{array}$ & $\begin{array}{l}\text { Strongly } \\
\text { agree } \\
\text { (5) }\end{array}$ \\
\hline \multicolumn{6}{|l|}{ market-garden produce* } \\
\hline \multicolumn{6}{|c|}{$\begin{array}{l}\text { cultivated or elaborated without chemical } \\
\text { agents }\end{array}$} \\
\hline \multicolumn{6}{|c|}{ integral products* } \\
\hline \multicolumn{6}{|l|}{$\begin{array}{l}\text { those without colourings or artificial } \\
\text { additives* }\end{array}$} \\
\hline those with a certification seal & & & & & \\
\hline
\end{tabular}

* In items indicated, the correct scale is exactly the opposite, which was taken into consideration when selecting the subsample. The objective of the presentation of the different, positively written items is to avoid influencing answers or giving hints.

Source: Own elaboration.

\section{Annex 2}

Demographic population, sample and subsample characteristics of Castilla-La Mancha consumers

\begin{tabular}{|c|c|c|c|c|}
\hline \multicolumn{2}{|c|}{ Variables } & \multirow{2}{*}{ Population $^{\text {a }}$} & \multirow{2}{*}{$\begin{array}{c}\begin{array}{c}\text { Sample } \\
(\mathrm{n}=463)\end{array} \\
48.6\end{array}$} & \multirow{2}{*}{$\begin{array}{c}\begin{array}{c}\text { Subsample } \\
(\mathbf{n}=\mathbf{2 1 5})\end{array} \\
47.9\end{array}$} \\
\hline Sor (0/) & Men & & & \\
\hline $\operatorname{sex}(\%)$ & Women & 50.1 & 51.4 & 52.1 \\
\hline \multirow{4}{*}{ Labour situation (\%) } & Agriculture & 6.6 & 8.1 & 8.4 \\
\hline & Industry & 22.5 & 16.8 & 16.8 \\
\hline & Services & 37.9 & 33.7 & 42.5 \\
\hline & Pensioner & 33.0 & 41.4 & 32.2 \\
\hline \multirow{4}{*}{ Level of studies (\%) } & No studies & 7.3 & 13.9 & 9.4 \\
\hline & Elementary & 40.2 & 34.4 & 23.5 \\
\hline & High school & 39.2 & 24.0 & 27.7 \\
\hline & College & 13.3 & 27.7 & 39.4 \\
\hline \multirow{4}{*}{ Age (\%) } & 18 to 34 years old & 34.5 & 29.6 & 40.0 \\
\hline & 35 to 49 years old & 25.0 & 32.2 & 31.6 \\
\hline & 50 to 64 years old & 16.9 & 13.6 & 12.6 \\
\hline & over 65 years old & 23.6 & 24.6 & 15.8 \\
\hline \multirow{5}{*}{ Monthly family income (\%) } & $<900 €$ & 24.7 & 22.0 & 17.2 \\
\hline & $\geq 900 €$ to $<1.500 €$ & 19.3 & 38.1 & 35.4 \\
\hline & $\geq 1.500 €$ to $<2.100 €$ & 17.0 & 31.5 & 36.8 \\
\hline & $\geq 2.100 €$ to $<3.000 €$ & 14.8 & 5.9 & 6.7 \\
\hline & $>3.000 €$ & 10.4 & 2.4 & 3.8 \\
\hline \multirow{2}{*}{ Habitat (\%) } & Rural & 50.7 & 75.6 & 73.0 \\
\hline & Urban & 49.3 & 24.4 & 27.0 \\
\hline
\end{tabular}

a Source: National Statistics Institute (2002)

Source: Own elaboration. 
